\title{
THE EFFECT OF VARIATIONS IN SOLUTE EXCRETION AND VASOPRESSIN DOSAGE ON THE EXCRETION OF WATER IN THE DOG
}

\author{
By JACK ORLOFF, HENRY N. WAGNER, JR., AND DOUGLAS G. DAVIDSON \\ (From the Laboratory of Kidney and Electrolyte Metabolism, National Heart Institute, \\ National Institutes of Health, Bethesda, Md.)
}

(Submitted for publication September 23, 1957; accepted November 21, 1957)

It has been known for some time that osmotic diuretics may modify the effect of vasopressin on urine concentration $(1,2)$. However, it has been generally assumed that urine will remain hypertonic to plasma if sufficient hormone is administered irrespective of the extent of the solute diuresis. This conclusion was based on the thesis that the major action of vasopressin is to promote the elaboration of a hypertonic urine presumably by a process involving active water reabsorption. Smith (3) and Wesson and Anslow (4), on the other hand, have suggested that vasopressin increases permeability of the tubule membrane to water in the distal segment, permitting osmotic equilibration in this area, and thereby diminishing the volume of isosmotic fluid delivered to a hypothetical concentrating site in the collecting duct.

The experiments to be reported were designed to reexamine in a quantitative fashion the effect of solute excretion on the renal response to purified arginine vasopressin. The data have been interpreted in the light of present information concerning the probable mode and sites of action of the hormone.

\section{METHODS AND MATERIAL}

Experiments were performed on trained, unanesthetized female dogs weighing approximately $20 \mathrm{Kg}$. each. Preliminary studies were performed on animals which had undergone section of the supraoptico-hypophyseal tracts and pituitary stalk. Despite persistent polyuria and polydipsia it was impossible to rule out the presence of residual antidiuretic hormone in these animals. The infusion of hypertonic saline during water diuresis resulted in a gradual decrease in free water clearance $\left(\mathrm{C}_{\mathrm{H}_{2} \mathrm{O}}\right.$, see below), albeit at a lesser rate than in normal dogs; and further, early morning urine was invariably hypertonic to plasma. Consequently it was concluded that these preparations afforded no significant advantage over normal dogs for the purpose of these studies.

All experiments were performed following a 12 to 16 hour fast. Water was allowed ad lib. when necessary.
Dogs were loosely restrained and maintained in the supine position throughout the experimental procedure. Extraneous stimuli were reduced to a minimum to insure adequate suppression of antidiuretic hormone release in hydrated animals. Bladder urine was collected by means of a soft indwelling rubber catheter. At the beginning of each study the dogs were given a quantity of water by stomach tube equal to 3 per cent of their body weight. Thereafter this positive water balance was maintained by administering 2.5 per cent glucose in water intravenously at a rate sufficient to maintain plasma osmolality relatively constant. Solute diuresis was produced by intravenous administration of an isotonir. solution of mannitol into the opposite limb.

The clearance of inulin or creatinine was used as a measure of glomerular filtration rate. Creatinine was determined by the method of Kennedy, Hilton, and Berliner (5) and inulin by the.method of Walser, Davidson, and Orloff (6). Urine and plasma osmolality were determined cryoscopically using the instrument developed by Bowman, Trantham, and Caulfield (7). All solutions were administered intravenously using a constant infusion pump.

Purified arginine vasopressin (lot no. AVN-5) was provided through the courtesy of Dr. V. du Vigneaud and contained no oxytocin by amino acid analysis. The potency of vasopressin had been assayed on the basis of its pressor activity. Stability of the hormone in aqueous solution was insured by maintaining the $\mathrm{pH}$ of all infusions in which the hormone was incorporated at approximately 5.0. In those studies in which large doses were required, commercial vasopressin (Pitressin $\$$, Parke-Davis) was administered. A sufficient period of continuous vasopressin administration was allowed prior to the onset of all studies to insure stability of effect. This period of equilibration, designed to establish an approximately steady state, varied from 20 to 160 minutes and was inversely related to the magnitude of the dose.

Since changes in glomerular filtration rate as well as variations in the dosage of vasopressin and solute excretion may influence urinary water excretion, all dogs were maintained on a relatively constant high protein food intake. Constancy of both the diet and the state of hydration minimized daily variations in filtration rate in individual animals. Consequently it was possible to consider solute excretion and the dosage of vasopressin as the major variables in these studies, and changes in glomerular filtration rate of minor significance in this regard. 


\section{RESULTS}

I. The relationship between urine flow and solute excretion during suppression of antidiuretic hormone $(A D H)$ release and in the presence of maximal vasopressin activity

The relationship between urine flow and solute excretion during suppression of endogenous antidiuretic hormone release was examined in three normal dogs. These data were required to afford a basis for the subsequent comparison of the effects of graded doses of vasopressin on the relationship. A representative experiment is presented in Table I. The results of all studies are depicted in Figure 1 (upper curve). Each point on the graph represents an individual collection period. Urine flow is plotted on the ordinate and osmolar clearance $\left(\mathrm{C}_{\mathrm{osm}}\right)$ on the abscissa. Solute-free water clearance $\left(\mathrm{C}_{\mathrm{H}_{2} \mathrm{O}}\right)$ is the vertical distance between the diagonal line (isosmotic parameter) and the experimentally derived point. ${ }^{1}$ It is apparent that in the "absence" of endogenous $\mathrm{ADH}$, solute-free water clearance rose progressively as the excretion of solute increased. Al-

1 According to Wesson and Anslow (4), hypotonic urine may be considered as consisting of two hypothetical moieties: 1) an isosmotic portion (referred to as osmolar clearance [ $\mathrm{C}_{\mathrm{osm}}$ ] and equal to $\mathrm{U}_{\text {osm }} \mathrm{V} / \mathrm{P}_{\text {osm }}$, where $U_{o s m}$ and $P_{o s m}$ refer to urine and plasma osmolality, respectively, and $\mathrm{V}$ to urine flow in $\mathrm{ml}$. per minute), and 2) an additional amount of solute-free water equal in volume to that which would have to be added to the isosmotic moiety to reduce its concentration to that observed (referred to as $\mathrm{C}_{\mathrm{H}_{2} \mathrm{O}}$ ). Thus, $\mathrm{V}$ equals $\mathrm{C}_{\mathrm{osm}}$ plus $\mathrm{C}_{\mathrm{H}_{2} \mathrm{O}}$. Hypertonic urine, on the other hand, is depicted as being made up of an isosmotic portion ( $\mathrm{C}_{\text {osm }}$ ) less that amount of water which would have to be abstracted from it to produce the observed hypertonicity (referred to as $\left.\mathrm{T}^{\mathrm{c}} \mathrm{H}_{2} \mathrm{O}\right)$. Thus, $\mathrm{T}^{\mathrm{c}} \mathrm{H}_{2 \mathrm{O}}$ equals $\mathrm{C}_{\mathrm{osm}}$ minus V. Although this has proved to be a useful concept, it should not be construed as necessarily affording any insight into the mechanism of urinary dilution and concentration. Unless so recognized, the calculations may be misleading. Thus, during water diuresis, $\mathrm{C}_{\mathrm{H}_{20} \mathrm{O}}$ should not be visualized as depicting the total amount of water freed by sodium chloride abstraction from isosmotic urine but may well be the algebraic sum of water freed in this manner minus that lost by simple diffusion out of the renal tubule. The observed $\mathrm{C}_{\mathrm{H}_{2} \mathrm{O}}$ will therefore be equal to the water freed minus the sum of that diffusing out at the same site or elsewhere in the diluting segment and that abstracted in the concentrating site. Similar considerations apply to the calculation of $\mathrm{T}^{\mathbf{c}} \mathrm{H}_{2} \mathrm{O}$ since this too may represent the resultant of a number of processes, i.e., water freeing, back-diffusion, and a terminal process which results in hypertonicity.
TABLE I

Effect of solute excretion on free water clearance during suppression of endogenous antidiuretic hormone release (Dog L., $16 \mathrm{Kg}$.)

\begin{tabular}{|c|c|c|c|c|c|}
\hline Time & $\begin{array}{l}\text { Urine } \\
\text { flow }\end{array}$ & $C_{o s m}$ & $\mathrm{C}_{\mathrm{H} Y \mathrm{O}}$ & $C_{a r}$ & $P_{\text {osm }}$ \\
\hline
\end{tabular}

$0 \quad 480 \mathrm{ml} . \mathrm{H}_{2} \mathrm{O}$ administered by stomach tube

10 Infuse $12 \mathrm{mg} . / \mathrm{min}$. of creatinine in $10 \mathrm{ml} . /$ min. of $2.5 \%$ dextrose in water

\begin{tabular}{|c|c|c|c|c|c|}
\hline $\begin{array}{c}104-124 \\
-148 \\
-164\end{array}$ & $\begin{array}{l}7.4 \\
7.1 \\
7.6\end{array}$ & $\begin{array}{l}2.2 \\
2.0 \\
2.0\end{array}$ & $\begin{array}{l}5.2 \\
5.1 \\
5.6\end{array}$ & $\begin{array}{l}66 \\
62 \\
62\end{array}$ & $\begin{array}{l}270 \\
270 \\
268\end{array}$ \\
\hline 166 & \multicolumn{5}{|c|}{$\begin{array}{l}\text { Begin additional infusion of } 5 \% \text { mannitol } \\
\text { in } \mathrm{H}_{2} \mathrm{O} \text { at } 14 \mathrm{ml} . / \mathrm{min} \text {. }\end{array}$} \\
\hline $164-200$ & 10.9 & 4.1 & 6.9 & 59 & 268 \\
\hline 201 & \multicolumn{5}{|c|}{$\begin{array}{l}\text { Increase dextrose infusion to } 14 \mathrm{ml} . / \mathrm{min} \text {. } \\
\text { Decrease mannitol to } 5 \mathrm{ml} . / \mathrm{min} \text {. }\end{array}$} \\
\hline 216 & \multicolumn{5}{|c|}{ Decrease dextrose infusion to $10.5 \mathrm{ml} . / \mathrm{min}$. } \\
\hline $\begin{array}{c}200-230 \\
-260 \\
-290 \\
-320 \\
-380\end{array}$ & $\begin{array}{l}12.8 \\
12.6 \\
13.4 \\
14.8 \\
17.6\end{array}$ & $\begin{array}{l}6.1 \\
6.3 \\
6.7 \\
7.5 \\
9.0\end{array}$ & $\begin{array}{l}6.7 \\
6.4 \\
6.7 \\
7.3 \\
8.6\end{array}$ & $\begin{array}{l}56 \\
58 \\
60 \\
66 \\
76\end{array}$ & $\begin{array}{l}270 \\
269 \\
268 \\
269 \\
273\end{array}$ \\
\hline 380 & \multicolumn{5}{|c|}{ Increase dextrose infusion to $14 \mathrm{ml} . / \mathrm{min}$. } \\
\hline $\begin{array}{l}380-406 \\
-424\end{array}$ & $\begin{array}{l}17.5 \\
18.4\end{array}$ & $\begin{array}{l}9.0 \\
9.1\end{array}$ & $\begin{array}{l}8.5 \\
9.1\end{array}$ & $\begin{array}{l}79 \\
82\end{array}$ & $\begin{array}{l}272 \\
271\end{array}$ \\
\hline
\end{tabular}

though a concomitant rise in sodium excretion was noted uniformly, it was not possible to distinguish between the effects of mannitol and sodium excretion on the results.

The effect of $50 \mathrm{mU}$ per $\mathrm{Kg}$. per hour of purified arginine vasopressin administered to the three dogs during combined mannitol and water diuresis is depicted in the lower curve (Figure 1). Under these circumstances urine remained hypertonic to plasma throughout the entire range of solute excretion examined. If sufficient time were allowed to achieve a maximal or steady state effect (60 to 90 minutes at this dosage of vaspressin) $5 \mathrm{mU}$ per $\mathrm{Kg}$. per hour of purified hormone was sufficient in some studies to produce effects indistinguishable from those noted with the larger dose. Consequently it may be concluded that the relationship depicted in the lower curve represents the effect of "maximal" $\mathrm{ADH}$ activity for the range of solute excretion examined.

\section{The relationship between urine flow and solute excretion during administration of submaximal doses of vasopressin}

Fifteen studies in the three dogs were performed during which vasopressin was adminis- 


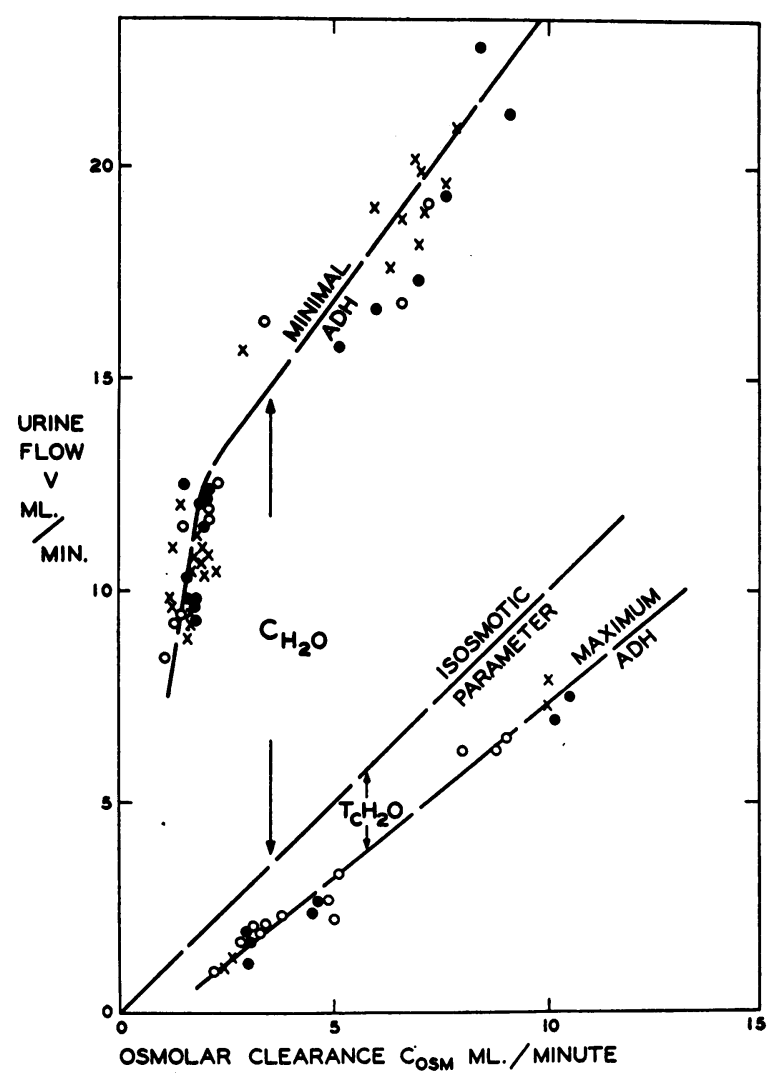

Fig. 1. The Relationship Between Urine Flow ANd Solute Excretion in the AbSence of ADH and During the Administration of "Maximal" Doses of VASOPRESSIN

tered in doses of either $0.5,1.0,1.5$ or $4.0 \mathrm{mU}$ per $\mathrm{Kg}$. per hour. The results from all experiments are graphically illustrated in Figure 2. Each symbol represents an individual collection period. Although as noted above it was not always possible to distinguish between the effects of 5 and $50 \mathrm{mU}$ per $\mathrm{Kg}$. per hour of vasopressin once a steady state had been achieved, at the intermediate dosages marked differences in response were noted. In the range of 0.5 to 1.5 $\mathrm{mU}$ per $\mathrm{Kg}$. per hour increased rates of vasopressin clearly resulted in lower rates of solutefree water clearance. ${ }^{2}$ Although data in all studies were qualitatively similar, in that $\mathrm{C}_{\mathrm{H}_{2} \mathrm{O}}$ diminished at the higher rates of hormone administration in single experiments, the absolute values of $\mathrm{C}_{\mathrm{H}_{2} \mathrm{O}}$ at comparable $\mathrm{C}_{\mathrm{osm}}$ were sufficiently dif-

2 In one study, it was necessary to administer $4 \mathrm{mU}$ per $\mathrm{Kg}$. per hour of vasopressin to effect a marked fall in $\mathrm{C}_{\mathrm{H}_{2} \mathrm{O}}$. ferent in some studies at the same vasopressin dosage to preclude any precise quantitative comparison between the dogs. This is to be expected in any biological study of this nature, but is noted in order to emphasize the difficulty of predicting with any degree of precision the response in dogs to a specific dosage of vasopressin insofar as $\mathrm{C}_{\mathrm{H}_{2} \mathrm{O}}$ is concerned. It should be noted that urine remained hypotonic to plasma during the administration of either 0.5 or $1.0 \mathrm{mU}$ per $\mathrm{Kg}$. per hour of vasopressin. Urine hypertonicity did not supervene at these dosages at the lowest rates of solute excretion despite administration of the hormone for as long as 160 minutes, a time presumably sufficient to achieve a steady state. When $1.5 \mathrm{mU}$ per $\mathrm{Kg}$. per hour ( $4 \mathrm{mU}$. per $\mathrm{Kg}$. per hour in one study) of arginine vasopressin was administered, hypertonic urine was elaborated only at the lower rates of solute excretion. At higher rates of solute excretion and despite the continuing administration of the same dosage of vasopressin, urine became hypotonic and $\mathrm{C}_{\mathrm{H}_{2} \mathrm{O}}$ rose. The change in urine concentration from hypertonic to hypotonic was not observed at higher

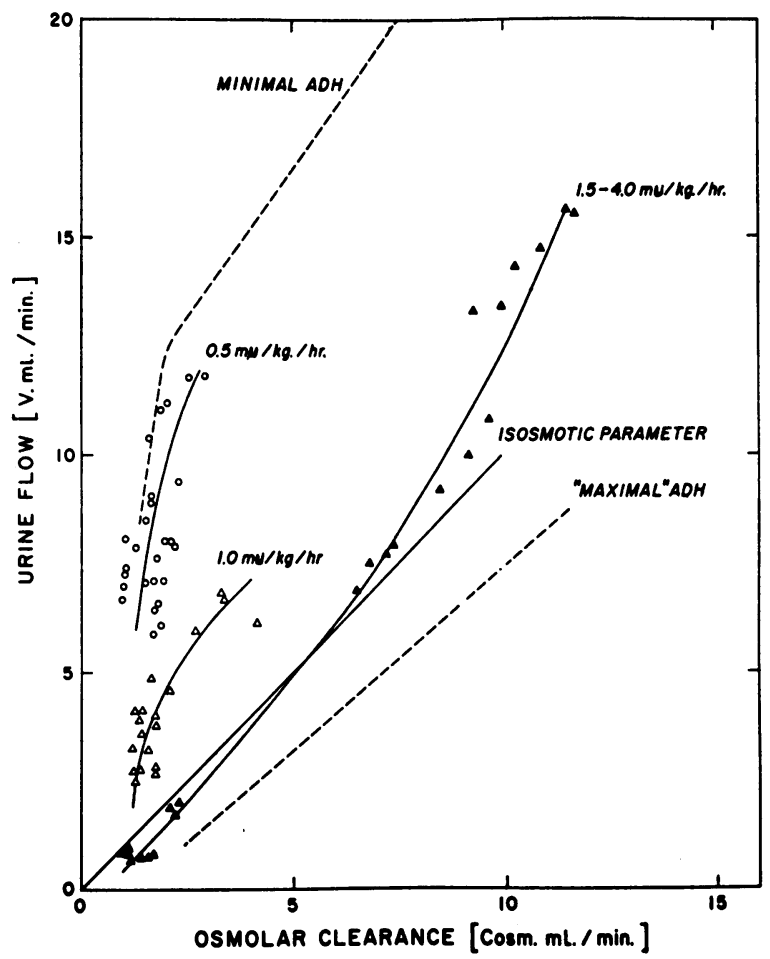

Fig. 2. The Relationship Between Urine Flow and Solute Excretion During the Administration of Graded Doses of VASOPRESSIN 
TABLE II

Effect of vasopressin dosage on free water clearance (Dog T., $19 \mathrm{Kg}$.)

\begin{tabular}{|c|c|c|c|c|c|}
\hline Time & $\begin{array}{l}\text { Urine } \\
\text { flow }\end{array}$ & Cosm & $\mathrm{C}_{\mathrm{H} 20}$ & $\mathrm{Car}_{\mathrm{r}}$ & Posm \\
\hline $\begin{array}{c}\min . \\
0 \\
14\end{array}$ & \multicolumn{5}{|c|}{$\begin{array}{l}\text { ml./min. } \quad \begin{array}{c}\mu 0 s m / K g \\
H, O\end{array} \\
570 \mathrm{ml} . \mathrm{H}_{2} \mathrm{O} \text { administered by stomach tube } \\
\text { Infuse } 15 \mathrm{mg} . / \mathrm{min} \text {. creatinine in } 5.0 \mathrm{ml} . / \\
\text { min. of } 2.5 \% \text { dextrose in } \mathrm{H}_{2} \mathrm{O}\end{array}$} \\
\hline $\begin{array}{c}123-133 \\
-143 \\
-153\end{array}$ & $\begin{array}{l}10.8 \\
11.2 \\
11.3\end{array}$ & $\begin{array}{l}1.6 \\
1.6 \\
1.5\end{array}$ & $\begin{array}{l}9.2 \\
9.6 \\
9.8\end{array}$ & $\begin{array}{l}98 \\
96 \\
94\end{array}$ & $\begin{array}{l}275 \\
274 \\
274\end{array}$ \\
\hline \multirow[t]{2}{*}{158} & \multicolumn{5}{|c|}{$\begin{array}{l}\text { Begin infusion of } 1.5 \mathrm{mU} / \mathrm{Kg} . / \mathrm{hr} \text {. of argi- } \\
\text { nine vasopressin }\end{array}$} \\
\hline & \multicolumn{5}{|c|}{ Decrease dextrose infusion to $0.5 \mathrm{ml} . / \mathrm{min}$. } \\
\hline $\begin{array}{c}153-163 \\
-173 \\
-183\end{array}$ & $\begin{array}{l}1.9 \\
2.1 \\
1.7\end{array}$ & $\begin{array}{l}2.1 \\
2.3 \\
2.2\end{array}$ & $\begin{array}{l}-0.20 \\
-0.20 \\
-0.50\end{array}$ & $\begin{array}{l}102 \\
102 \\
101\end{array}$ & $\begin{array}{l}259 \\
259 \\
259\end{array}$ \\
\hline 185 & \multicolumn{5}{|c|}{$\begin{array}{l}\text { Begin infusion of } 5 \% \text { mannitol at } 4.6 \mathrm{ml} . / \\
\text { min.; dextrose at } 4.5 \mathrm{ml} . / \mathrm{min} \text {. }\end{array}$} \\
\hline $\begin{array}{c}220-230 \\
-240 \\
-250\end{array}$ & $\begin{array}{l}6.9 \\
7.5 \\
7.7\end{array}$ & $\begin{array}{l}6.5 \\
6.8 \\
7.1\end{array}$ & $\begin{array}{l}0.40 \\
0.70 \\
0.60\end{array}$ & $\begin{array}{l}108 \\
108 \\
106\end{array}$ & $\begin{array}{l}260 \\
260 \\
261\end{array}$ \\
\hline 255 & \multicolumn{5}{|c|}{$\begin{array}{l}\text { Begin infusion of } 6.5 \mathrm{mU} / \mathrm{Kg} \text {. } / \mathrm{hr} \text {. of argi- } \\
\text { nine vasopressin }\end{array}$} \\
\hline $\begin{array}{l}250-270 \\
-290 \\
-312 \\
-322\end{array}$ & $\begin{array}{l}7.9 \\
6.0 \\
5.3 \\
5.1\end{array}$ & $\begin{array}{l}7.4 \\
8.0 \\
8.3 \\
7.7\end{array}$ & $\begin{array}{l}-0.5 \\
-2.0 \\
-3.0 \\
-2.6\end{array}$ & $\begin{array}{l}113 \\
104 \\
108 \\
106\end{array}$ & $\begin{array}{l}262 \\
262 \\
260 \\
260\end{array}$ \\
\hline
\end{tabular}

rates of vasopressin administration over the range of solute excretion examined in these studies. ${ }^{8}$ The transition in urine concentration from hypertonic to hypotonic observed when 1.5 to $4.0 \mathrm{mU}$ per $\mathrm{Kg}$. per hour of vasopressin were administered is clearly due to the insufficiency of the vasopressin dosage in the face of an acute rise in solute excretion. The argument is further supported by the results of studies in which a reversal of the transition, i.e., the reestablishment of hypertonicity, was observed when additional vasopressin was administered. The details of one such study are presented in Table II. A summary of the experiments is tabulated in Table III.

\section{DISCUSSION}

It had been assumed for many years that the major action of vasopressin was to induce the

${ }^{3}$ In contrast to the results of these studies, the excretion of a hypotonic urine has been observed in some studies during the administration of presumably adequate amounts of commercial vasopressin (Pitressin(B). In these both a rise in plasma osmolality and massive osmotic diuresis were induced by the administration of hypertonic mannitol or saline solutions (8). elaboration of a hypertonic urine. Recently Smith (3) and Wesson and Anslow (4) suggested that rather than promote active reabsorption of water from either hypotonic or isotonic fluid, vasopressin acts to increase tubule membrane permeability to water in the distal segment, thereby permitting outward diffusion of water along an osmotic gradient. Their view of the sequence of events in urinary dilution and concentration is as follows: Dilution, the freeing of water from isotonic urine, is effected by abstraction of sodium and anion in an area of tubule impermeable to water. In the presence of antidiuretic hormone, the tubule membrane in this segment becomes freely permeable to water. Water diffuses out along the osmotic gradient developed by electrolyte abstraction until equilibrium is achieved. Elaboration of hypertonic urine is presumably accomplished by water abstraction from residual isosmotic urine in a more distal area. Whether this last process was influenced by $\mathrm{ADH}$ had not been determined. That vasopressin affects the permeability of the tubule membrane to water is in accord with the observations of Koefoed-Johnsen and Ussing (9) in frog skin. These investigators noted an increase in net water flux across isolated frog skin under the influence of neurohypophyseal extract and concluded on the basis of this and other data that neurohypophyseal hormones produce this effect by increasing pore size within the skin. Despite acceptance of this as the probable mode of action of vasopressin in the renal tubule as well as in frog skin, it is not possible to interpret all of the findings observed

TABLE III

Effect of vasopressin dosage and solute excretion on clearance of free water *

\begin{tabular}{|c|c|c|c|c|c|c|}
\hline \multirow{2}{*}{$\begin{array}{c}\text { Experi- } \\
\text { ment } \\
\text { no. }\end{array}$} & \multicolumn{2}{|c|}{$\underset{\text { ADH }}{\text { Submaximal }}$} & \multicolumn{2}{|c|}{$\begin{array}{c}\text { Solute diuresis } \\
\text { Submaximal } \\
\text { ADH } †\end{array}$} & \multicolumn{2}{|c|}{$\begin{array}{c}\text { Solute diuresis } \\
\text { "Maximal" } \\
\text { ADH } \ddagger\end{array}$} \\
\hline & $\mathrm{C}_{\text {osm }}$ & $\mathrm{C}_{\mathrm{H} 20}$ & Cosm & $\mathrm{C}_{\mathrm{HzO}}$ & $\mathrm{C}_{\mathrm{osm}}$ & $\mathrm{C}_{\mathrm{B2}} \mathrm{O}$ \\
\hline $\begin{array}{l}1 \\
2 \\
3 \\
4\end{array}$ & $\begin{array}{l}2.2 \\
1.1 \\
1.7 \\
1.1\end{array}$ & $\begin{array}{l}-0.5 \\
-0.4 \\
-0.9 \\
-0.2\end{array}$ & $\begin{array}{r}6.8 \\
9.7 \\
10.9 \\
11.5\end{array}$ & $\begin{array}{l}0.7 \\
1.1 \\
3.8 \\
4.1\end{array}$ & $\begin{array}{r}8.3 \\
12.2 \\
11.1 \\
12.1\end{array}$ & $\begin{array}{l}-3.0 \\
-1.6 \\
-0.9 \\
-1.1\end{array}$ \\
\hline
\end{tabular}

* Each datum represents a single period during the course of the study.

$\dagger$ Initial (submaximal) vasopressin dosage varied between 1.5 to $4.0 \mathrm{mU}$ per $\mathrm{Kg}$. per hour of purified vasopressin.

† "Maximal" vasopressin dosage varied from $6.5 \mathrm{mU}$ per $\mathrm{Kg}$. per hour of purified vasopressin to $600 \mathrm{mU}$ per $\mathrm{Kg}$. per hour of commercial vasopressin. 
in this and other studies $(2,10)$ strictly within the framework of Smith's and Wesson and Anslow's hypothesis. One would expect, were the membrane freely permeable to water during vasopressin administration, that superimposed osmotic diuresis would invariably result in some degree of urine hypertonicity. It is likely that: 1 ) permeability to water is never absent, and therefore that the rate of outward diffusion of water is dependent on intraluminal osmotic pressure even during water diuresis (11); and 2) the permeability of the tubule membrane in the distal segment varies in a graded fashion as a function of the dosage of vasopressin (12).

The first of these arguments, i.e., the partial permeability to water even in the absence of $\mathrm{ADH}$, has been discussed by Orloff and Walser (11). They observed a progressive rise in $\mathrm{C}_{\mathrm{H}_{2} \mathrm{O}}$ during combined water and solute diuresis in patients with nephrogenic diabetes insipidus, and concluded that this was due in part to a progressive decline in the rate of diffusion of freed water out of the tubule as a consequence of the osmotic restraint of nonabsorbed solute in tubule urine. In other terms, the presence of solute in tubule urine decreases the activity of water and thereby its rate of outward diffusion. ${ }^{4}$ The results of a number of other studies $(13,14)$ as well as those reported here in dogs during $\mathrm{ADH}$ suppression are consistent with this view. In the presence of large amounts of vasopressin, on the other hand, permeability may be sufficient to permit equilibration of water on both sides of the tubule membrane despite the opposing influence of intratubular solute. Under these circumstances the terminal concentrating process (see below) will effect the excretion of a hypertonic urine.

Intermediate dosages of vasopressin will produce effects dependent on the degree of membrane permeability achieved and the extent of the solute diuresis. The studies of Hollander, Williams, Fordham, and Welt (12) clearly indicate that vasopressin does affect membrane permeability

4 It is also recognized that the rise in $\mathrm{C}_{\mathrm{H}_{2} \mathrm{O}}$ observed during solute diuresis could be accounted for on the basis of increased $\mathrm{NaCl}$ reabsorption. Though this possibility cannot be ruled out, and an increase in $\mathrm{NaCl}$ reabsorption may contribute to some of the changes observed, the osmotic effect of solute must be of significance in this regard (11). in a graded fashion. The results observed in these studies may be similarly interpreted. Consequently, the observation that initial hypertonicity of urine is not maintained as solute excretion rises, unless greater amounts of hormone are administered, indicates that under these circumstances (submaximal ADH activity) membrane permeability is insufficient to permit complete osmotic equilibration. Presumably both flow and the osmotic gradient are such as to limit the backdiffusion of water, permitting delivery of a larger volume of hypotonic urine to the concentrating site. Thus, during submaximal $\mathrm{ADH}$ activity and osmotic diuresis, a part of the water "freed" diffuses out of the urine in both the segment in which free water is produced and in the terminal concentrating area. As vasopressin dosage increases, although the rate at which solute is reabsorbed to produce free water need not necessarily change, more water leaves the tubule by diffusion as a consequence of a further increase in membrane permeability. Urine will become hypertonic at differing levels of solute excretion depending upon vasopressin dosage. In essence it is suggested that solute excretion, insofar as it affects intraluminal osmotic pressure, and vasopressin have opposing effects, the former diminishing outward diffusion of "freed" water and the latter enhancing it. Which effect is greater will determine whether urine is hypotonic or isotonic when delivered to the segment in which water can be removed to produce hypertonicity. The presumption in these studies was that once pore size became "maximal," osmotic equilibrium was achieved at all rates of flow and solute excretion examined, and urine hypertonicity developed uniformly. This does not preclude the probability that at even higher rates of solute excretion back-diffusion of water may lag sufficiently to permit excretion of hypotonic urine despite "maximal" vasopressin activity. Whether the data obtained during massive osmotic diuresis in dogs in which plasma osmolality was elevated (8), as well as the data of Anslow and Wesson (10), may be explained on this basis as had been suggested by Mudge, Foulks, and Gilman (15) has not yet been determined.

The elaboration of hypertonic urine requires terminal abstraction of water in a tubule area relatively impermeable to solute. Though this process may occur to a limited degree in the absence of 
hormones (16) the inability to excrete maximally concentrated urine under the conditions of the experiments reported by Berliner and Davidson (16) is consistent with the view that the terminal concentrating process may also be enhanced by ADH. This would presumably entail an increase in water permeability in this area as well as at the diluting site, thereby permitting increased outward diffusion of water. This is in accord with the hypothesis of Wirz (17) who suggested that terminal concentration is the result of equilibration of collecting duct urine with medullary interstitial fluid, the concentration of which is greatly in excess of plasma.

Development of urine hypotonicity during vasopressin administration and osmotic diuresis has been observed by de Wardener and del Greco (2) in patients with diabetes insipidus, and by Anslow and Wesson (10) in dogs. The first group of authors recognized that this was due to insufficiency of vasopressin dosage. They concluded, however, that contrary to current views urine leaving the proximal segment is always hypotonic. This was based on the inference that osmotic diuresis effects the delivery of greater amounts of proximal urine to the concentrating site and that vasopressin merely functions to promote terminal abstraction of water from such dilute pre-urine. It is apparent that their data as well as those reported above may be interpreted within the context of the thesis that proximal urine is isosmotic and that vasopressin promotes outward diffusion of water throughout the distal segment. Anslow and Wesson (10), on the other hand, ascribed their results to Pitressin ${ }^{\circledR}$ "insensitivity" of unknown origin. Though their studies are not completely analogous to those reported here, the phenomenon may have been the result of submaximal amounts of hormone in the presence of solute diuresis. The dosage of vasopressin used by these investigators was not as great as that required in the present studies to promote persistent urine hypertonicity nor were precautions taken to prevent deterioration of vasopressin (acidification to $\mathrm{pH} 5.0$ ). Furthermore, the extent of the solute diuresis was in excess of that observed in these experiments.

It is not possible to extend the views of Shannon (18) and Lauson (19) on the physiological rate of secretion of hormone on the basis of these data other than to point out that one cannot assign an absolute value to the amount of endogenous or exogenous hormone required to promote an effect unless all conditions are clearly defined. Numerous factors, including solute excretion, glomerular filtration rate, the state of bodily hydration, and possibly adrenal activity, may affect urine osmolality directly or indirectly, and thereby may modify the character of the observed response to vasopressin. If one views vasopressin as an agent which merely alters membrane permeability in the diluting and concentrating areas of the kidney, then it is apparent that one cannot assess its relative activity under all circumstances merely by observing changes in urine flow and concentration.

\section{SUMMARY AND CONCLUSIONS}

The administration of varying dosages of purified vasopressin during combined water and solute diuresis in dogs results in a progressive decline in $\mathrm{C}_{\mathrm{H}_{2} \mathrm{O}}$ dependent on the dosage of hormone. The graded effect is such that at low rates of vasopressin administration a transition from hypertonic to hypotonic urine is noted as solute excretion rises. This transition may be reversed with maximally effective dosages of the hormone.

The data have been interpreted in the light of the thesis that vasopressin affects tubule membrane permeability in a graded fashion throughout the distal segment, both in the area where free water is present and in the terminal concentrating site. Osmotic equilibration of tubule fluid with renal interstitial tissue is essential for the elaboration of hypertonic urine. Since solute excretion and vasopressin exert opposing effects on the movement of water out of the tubule lumen into the interstitial space, net movement of water and the final urinary solute concentration are dependent on the relative contribution of each of these factors to the overall process.

\section{REFERENCES}

1. Adolph, E. F., and Ericson, G. Pituitrin and diuresis in man. Amer. J. Physiol. 1927, 79, 377.

2. de Wardener, H. E., and del Greco, F. The influence of solute excretion rate on the production of a hypotonic urine in man. Clin. Sci. 1955, 14, 715.

3. Smith, H. W. The Kidney, Structure and Function in Health and Disease. New York, Oxford Univ. Press, 1951. 
4. Wesson, L. G., Jr., and Anslow, W. P., Jr. Effect of osmotic and mercurial diuresis on simultaneous water diuresis. Amer. J. Physiol. 1952, 170, 255.

5. Kennedy, T. J., Jr., Hilton, J. G., and Berliner, R. W. Comparison of inulin and creatinine clearance in the normal dog. Amer. J. Physiol. 1952, 171, 164.

6. Walser, M., Davidson, D. G., and Orloff, J. The renal clearance of alkali-stable inulin. J. clin. Invest. $1955,34,1520$.

7. Bowman, R. L., Trantham, H. V., and Caulfield, P. A. An instrument and method for rapid, dependable determination of freezing-point depression. J. Lab. clin. Med. 1954, 43, 310.

8. Orloff, J., Wagner, H. N., Jr., and Davidson, D. G. Unpublished observations.

9. Koefoed-Johnsen, V., and Ussing, H. H. The contributions of diffusion and flow to the passage of $\mathrm{D}_{2} \mathrm{O}$ through the living membrane. Acta physiol. scand. 1953, 28, 60.

10. Anslow, W. P., Jr., and Wesson, L. G., Jr. Effect of sustained, graded urea diuresis on water and electrolyte excretion. Amer. J. Physiol. 1955, 180, 605.

11. Orloff, J., and Walser, M. Water and solute excretion in Pitressin-resistant diabetes insipidus. Clin. Res. Proc. 1956, 4, 136.

12. Hollander, W., Jr., Williams, T. F., Fordham, C. C., III, and Welt, L. G. A study of the quantitative relationship between antidiuretic hormone (vasopressin) and the renal tubular reabsorption of water. J. clin. Invest. 1957, 36, 1059.

13. Rosenbaum, J. D., Nelson, W. P., III, Strauss, M. B., Davis, R. K., and Rossmeisl, E. C. Variation in the diuretic response to ingested water related to the renal excretion of solutes. J. clin. Invest. 1953, 32, 394.

14. Kleeman, C. R., Epstein, F. H., and White, C. The effect of variations in solute excretion and glomerular filtration on water diuresis. J. clin. Invest. $1956,35,749$.

15. Mudge, G. H., Foulks, J., and Gilman, A. Effect of urea diuresis on renal excretion of electrolytes. Amer. J. Physiol. 1949, 158, 218.

16. Berliner, R. W., and Davidson, D. G. Production of hypertonic urine in the absence of pituitary antidiuretic hormone. J. clin. Invest. 1957, 36, 1416.

17. Wirz, $H$. The location of antidiuretic action in the mammalian kidney in The Neurohypophysis, $H$. Heller, Ed. New York, Academic Press Inc., 1957, p. 157.

18. Shannon, J. A. The control of the renal excretion of water. J. exp. Med. 1942, 76, 371.

19. Lauson, H. D. The problem of estimating the rate of secretion of antidiuretic hormone in man. Amer. J. Med. 1951, 11, 135. 